\title{
Conversion Narrative and Christian Identity: \\ 'How Christianity came to Iceland'
}

Conversion, in the Middle Ages as today, has a range of different meanings: as Muldoon has commented, it encompasses a 'spectrum' of experiences, not one. ${ }^{1}$ In the Hebrew and Greek Scriptures, the root meaning of the verbs used is 'to turn', 'to return', 'to repent'; in his Confessions, Augustine uses a range of word-forms with the root 'vert' ('to turn') in describing his own conversion (e.g. 'convert', 'avert', 'pervert', 'adverse', 'universe'). ${ }^{2}$ In a classic study of conversion in late Antiquity, Nock defined it as 'the re-orientation of the soul of an individual, his deliberate turning from indifference or from an earlier form of piety to another, a turning that implies a consciousness that the old was wrong and the new was right'. ${ }^{3}$ This is frequently quoted in works on conversion in the Middle Ages, with certain qualifications. Many historians have pointed out that this individualizing definition of conversion can hardly apply to the description of the large-scale conversion of whole peoples, for whom Christianity is just as likely to have been a pragmatic choice as a theological one. ${ }^{4}$ Some scholars prefer to use different terms for the conversion of peoples ('acculturation' or 'Christianization'), but it is not necessarily useful or accurate to reserve the term 'conversion' only for individuals: the biblical call to repent is, after all, addressed to the community as a whole. ${ }^{5}$ The other qualification is that, while Nock assumes that conversion represents a single turning point, most would now conceive of it as a process: Morrison has shown that, in twelfth-century monastic writing, conversion is predominantly understood as a way of life, a process of 'empathetic transformation' that begins with entry into the monastic life and ends only with death. ${ }^{6}$ Although one might argue that his definition applies only to an intellectual élite, the idea of conversion as a process has the support of contemporary psychologists like Rambo, who would divide it into stages such as 'crisis', 'quest', 'encounter', 'interaction' and so on. ${ }^{7}$ Conversion, then, can be individual or communal, personal transformation or institutional affiliation; it can be depicted as a single moment of crisis or as a lifelong process of change.

Just as difficult to pin down is the relationship between the experience of conversion and its representation in narrative, which is often dismissed as derivative and therefore suspect in historical terms. ${ }^{8}$ It is common for those writing on conversion to distinguish between the experience of conversion, which is 'beyond thought and words' and the narrative of conversion, which is retrospective and 
rationalized. Morrison points out that the Latin conversio is a metaphor from manufacturing processes in the arts and crafts (the "transformation of one substance into another'), and thus that there is always an artistic, even perhaps a consciously fictional element to conversion narratives: it is only through the poetic imagination that the ineffable ('the reorientation of the soul') can be expressed. ${ }^{9}$ Conversion, according to Bernard of Clairvaux, takes place in a supernatural dimension freed from the constraints of language, so concealment is a condition of both the experience of conversion and the narrative that results. ${ }^{10}$ Some scholars distinguish between 'primary' and 'secondary' conversion, arguing that the religious experience is followed by a second conversion of 'life into text'. ${ }^{11}$ Yet if conversion is always a 'turning' from and/or to, if it is always a process, then one might argue that conversion can only be expressed and apprehended through narrative, even if the religious experience at the heart of it cannot. As Fredrikson has argued: ${ }^{12}$

To see a content filled moment of conversion is to have constructed a narrative whereby that moment emerges retrospectively as the origin of (and justification for) one's present.

Narrative is the primary genre used in the Bible to speak of conversion; Szpiech points out that the conversion of St Paul in Acts undergoes 'a process of narrativization' by being told and then retold three times. ${ }^{13}$ St Augustine, in the garden in Milan, hears a voice chanting tolle lege ('take up and read'): this is not just 'conversion by the book', but conversion as a way of reading, a form of exegesis: a 'strong form of reading' or 're-reading' of one's life. ${ }^{14}$ Indeed, the way in which narrative shapes and orders the flow of experience might be thought of as parallel to the way in which God, in the Christian tradition, shapes and orders history: all narratives, in this sense, are conversion narratives - retrospective narratives, narratives ordered towards an end. ${ }^{15}$ As Ricœur has commented: 'Each literary plot is a sort of miniature version of the great plot that joins Apocalpyse and Genesis' ${ }^{16}$ More recently, it has even been argued that conversion narratives are not 'retrospective' so much as 'prospective': the text precedes and makes the experience of conversion, not the experience of conversion the text. ${ }^{17}$ The literary form of the conversion narrative therefore deserves close attention: rather than coming second to the experience of conversion, it is through narrative that conversion takes place. 
These views are supported by more recent work on conversion within the social sciences. Sociologists have argued that one thing that definitely changes when a person is converted is their 'universe of discourse': the way a person interprets the world and his or her relationship to it through language. ${ }^{18}$ A significant part of this change is the process of 'biographical reconstruction': the 'dismantling' and 'reconstituting' of one's past in such a way as to identify with the paradigms of the group. Rambo suggests that a key moment in the encounter of conversion comes when the convert perceives a point of contact (an 'impression point') between his or her own life story and the central narratives of the group: conversion is about entering into 'a new story' in which one's personal life experience is integrated into a theological system. ${ }^{19}$ In some evangelical movements, giving one's testimony is recognized as a crucial stage in conversion: the convert asserts his or her new identity as convert by retelling his or her story in accordance with the metaphors, images and narratives of the group. ${ }^{20}$ It may be relevant that the Norse verb for 'to convert' is snúa, which can also mean 'to translate'; conversion and translation are closely connected as creative and literary acts. Sociologists would argue that telling one's story is not separate from the process of conversion, but actually constitutive of it.

As for individuals, so for communities: conversion to Christianity is experienced and understood through narratives about conversion to Christianity. We see this in the narratives in which the Germanic peoples of medieval Europe told the story of their conversion: they too needed to remember and 'reconstitute' their past in such a way as to assert a new Christian identity for themselves. Participation in the Christian community meant the appropriation of biblical narratives, reconstructing the history of one's people so as to integrate it into a theological system. It meant entering into a new story: the story of salvation history. These narratives are not secondary to the conversion process; they are an intrinsic part of the process of converting.

Conversion history, then, is necessarily literary history: the history of how 'converting' peoples appropriated Christian narratives. ${ }^{21}$ Religious identity, like any other form of identity, requires the construction of continuity and sameness over time and space: Szpiech describes the convert as a 'chronotope', who 'embodies and reflects the entirety of salvation time, the before-and-after of figural Christian thought'. ${ }^{22}$ In Christian Identity in the Jewish and Graeco-Roman World, Lieu speaks of 'the focality of belonging to and being able to tell a story' and 'the powerful and empowering function, within the continuing tradition, of remembering a common 
faith narrative'. ${ }^{23}$ This is particularly the case for Judaism and Christianity, which are very much 'religions of remembrance'; Szpiech speaks of conversion as 'distinctively Christian' because it reflects so closely 'Christian notions of revelation, salvation and time' ${ }^{24}$ However, there are some challenges here. The continuity and sameness constitutive of Christian identity must be weighed against the discontinuity and difference that constitutes Christian conversion; the strengthening of local identity must be carefully balanced against the international and universalizing tendencies of Christianity. ${ }^{25}$ As Lieu herself points out, remembering in this context is an active process of 're-membering': it involves 'a deliberate not remembering' or 'remembering otherwise', perhaps even a 'denial of difference', a collective amnesia on whatever does not match the dominant narrative of the group. ${ }^{26}$ Although religious identity may appear stable, it in fact conceals variety and multiplicity: contest and struggle with alternative narratives are hidden behind an apparently united front. One might connect this with what Ricœur says about 'as yet untold stories' in life: 'a life story proceeds from untold and repressed stories in the direction of actual stories the subject can take up and hold as constitutive of his personal identity' ${ }^{27}$ It is with the recollection of a few 'as yet untold stories' that this paper is concerned.

Although my primary focus is Iceland, it is helpful to start by discussing a better-known story in Bede's Historia ecclesiastica, which furnishes a particularly good example of conversion as a 'strong form of reading', as allegorical exegesis. As Wormald and others have argued, Bede invests the English with shared identity on the basis of their spiritual unity, making use of the biblical theme of election to present the English as a 'chosen people' with a providential destiny of their own. ${ }^{28}$ Yet the conversion of the English is not just a local event, but their incorporation into the Universal Church; a fulfillment of Old Testament prophecies that God's word will reach to 'islands' at the end of the 'earth'. ${ }^{29}$ Bede's exegesis can be clearly discerned in his well-known account of the conversion of King Edwin, in which an anonymous advisor makes the famous speech about the sparrow flying through the lighted hall. As Fry recognized, this is the sparrow of Psalm 83 (84), which Augustine allegorizes in his Expositions of the Psalms as 'the heart' and who is promised 'a heavenly perch, an everlasting home'. ${ }^{30}$ Christianity, in this story, offers clear knowledge of what comes before and after life: it transforms a haunting image of transience into a master narrative within which each individual life finds its purpose. Likewise, Barrow has argued that the story about the high priest Coifi presents 'a sustained piece of literary 
inversion and biblical exegesis': the spear with which Coifi (recalling Caiaphas) desecrates the pagan shrines can be read as a type of the spear with which Christ's side is pierced, from which the waters of baptism flow. ${ }^{31}$ The shadowy visitor that appears to Edwin, she suggests, is a figura - the shadow of the Old Testament pointing through 'signs' to the New, an embodiment of 'typological reading'. Conversion, for Bede as for Augustine, is a 'theological interpretation of the past' ${ }^{32}$ Alternatively, one might think of allegorical exegesis itself as reiterating the process of converting; recollecting or redeeming hidden, lost or absent meanings and translating this 'loss' into eternal 'gain'. Poland argues that it 'repeats in miniature the crisis through which loss and death become gain and eternal life'. ${ }^{33}$

At the same time, Rowley has argued that Bede here struggles to make the material at his disposal fit the paradigm of conversion, that other stories 'untold' or 'repressed' can be perceived between the gaps of this 'meditation on the redemption'. ${ }^{34}$ There are alternative accounts of Edwin's conversion in British sources and in the Earliest Life of Gregory the Great, which Bede may have known; and his account can be broken down into three distinct and conflicting narratives, which he struggles to coordinate. ${ }^{35}$ Edwin's lack of miracles and the hesitancy - the deferral - of his conversion 'resist' Bede's desire to incorporate it through exegesis into his grand theological vision of God's intervention in the history of the English people. The obscurity of Edwin's visitor, his isolation and silent musings speak just as much of the opacity of God's will as of divine enlightenment and revelation.

Bede may well have been a source for the first written history of the Icelanders and the very earliest account of their conversion: Ari Porgilsson's Íslendingabók, written between c. $1122-1133 .{ }^{36}$ As I have argued elsewhere, Ari's depiction of the conversion is remarkably streamlined, based on the memory of a single person, Ari's foster-father Teitr, and recording the Icelanders' consensual decision to accept Christianity with a bare minimum of conflict and disagreement. ${ }^{37}$ Although theology seems to have been of less interest to Ari than statecraft, he nevertheless makes use of the biblical paradigm of migration and conversion so useful for the election of nations. Yet, even in his short history, we find the same 'dynamic of resistance and incorporation' that Rowley identifies in Bede.

On the surface, Ari's history is certainly marked by 'sameness and continuity over time and space' - to the extent that he might be said to neglect Nock's sense of conversion as a 'deliberate turning' and a 'consciousness that the old was wrong'. He 
cultivates this continuity so carefully that it is easy to miss the elegant maneuvers that allow him to present the arrival of Christianity in this way. Ari tells us that, before the Icelanders arrived, there were Irish Christians in Iceland: ${ }^{38}$

Pá váru hér menn kristnir, peir es Norðmenn kalla papa, en peir fóru síðan á braut, af pví at peir vildu eigi vesa hér við heiðna menn, ok létu eptir bœkr írskar ok bjõllur ok bagla; af pví mátti skilja, at peir váru menn írskir (p. 5)

There were then Christians here, whom the Northmen call papar, but they later went away, because they did not wish to stay here with heathens; and they left behind them Irish books and bells and staffs. From this it could be seen that they were Irishmen.

As often noted, these 'relics' serve to consecrate the land, suggesting that Iceland was Christian territory - sacred space - long before the actual conversion. ${ }^{39}$ Just as important, though, is the corresponding emptiness of the landscape: the absence of pagan shrines or temples (like Edwin's fana) that must be cleansed or destroyed before Christianity can gain ground. This stands in sharp contrast to later accounts of Iceland's conversion: in Porvalds páttr víðförla, Bishop Friðrekr must drive an evil spirit out of a rock in order to gain his first convert, and in Piðranda páttr ok Pórhalls, the prophet Pórhallr sees all the nature spirits in Iceland packing their bags to depart before the missionary Pangbrandr arrives from Norway. ${ }^{40}$ In Pórhalls páttr knapps, an angel appears to Pórhallr in a dream, telling him to break down his temple at once, and build a church when Christianity comes to Iceland; when they land in Iceland, Gizurr and Hjalti's first act is to destroy pagan shrines and build a church on the very same site. ${ }^{41}$ Ari, however, except for one tantalizing reference to hof ('temples'), does not mention any aspect of pagan cult: his Icelanders are preChristian, rather than pagan, and they do not enter into conflict, nor have any contact with the Irish Christians at all. This is particularly significant given that Ari dates the settlement of Iceland to the time 'es Ívarr Ragnarssonr loðbrókar lét drepa Eadmund enn helga Englakonung' ('when Ívarr, son of Ragnarr loðbrók had St Edmund, king of the Angles, killed'). In Ari's retelling, Iceland is not caught up in this dramatic conflict between Norse paganism and Christianity; it forms a self-contained island sanctuary, insulated from the violence of the surrounding world.

Ari mentions a 'saga' of Edmund, perhaps a written life, allowing him to coordinate the date of Iceland's settlement with the chronology of the Christian world. More significant, though, from a theological point of view, are the boekr ('books') that 
he claims the Irish Christians left behind. Like bells and staffs (Old Icelandic bagall, from Irish bachall), books are frequently the subject of miracles in Irish and British saints' lives: books written in the hand of St Columba are miraculously kept safe when dropped in water, and St Cuthbert's precious book (probably the Lindisfarne Gospels), washes up on the beach at Whitherne, dry and undamaged, when it falls out of the boat in which his body lies. ${ }^{42}$ For Ari, these books constitute the 'impression point': Iceland has entered into written history before the Northmen even arrive. They are a sign of Iceland's place in salvation history, in which Ari's boekling ('little book') - prefigured here - has its own modest role to play. In this sense, they function similarly to the mysterious figura in Bede, a 'figure' of the Old Testament, understood retrospectively to point towards the New. Conversion is an entry into Christian narrative, into the master plot between 'Apocalypse and Genesis'.

Another potential 'impression point' is the day and night that Porgeirr spends lying under his cloak, deciding whether to accept Christianity; a moment that is closely comparable with Edwin's silence as he muses over which religion to adopt. Like Edwin, Porgeirr stands here for the Icelandic people as a whole: the success of their conversion story will depend on what he decides. Jón Hnefill Aðalsteinsson has amassed significant evidence that links Porgeirr's 'lying out' with the practice of pagan divination, but there are biblical and hagiographic parallels too: Elijah wraps himself in his cloak to go out and hear the 'still, small voice of God' and Ezra sitting with his cloak torn in penitence for the Israelites' sins. ${ }^{43}$ In one of the best known and most frequently illustrated incidents in his life, St Martin draws his sword and cuts his cloak in two so that he can share it with a beggar; that night, he has a vision of Christ wearing the beggar's half. ${ }^{44}$ Ari here remembers Iceland's conversion in such a way as to infuse pagan practice with Christian meaning, drawing on the shared associations in both traditions. He uses the cloak, theologically, to acknowledge but also to conceal the 'reorientation of the soul' in the converting individual.

Ari's focus on a single story about the conversion is attractively ordered and compelling, allowing him to establish a high degree of continuity between pre- and post-conversion Iceland; but his focus comes at the cost of other more heterogeneous stories about early Christianity in Iceland. This can be seen in a couple of loose ends that 'resist' Ari's strongly unified reading. At the beginning of his chapter on the conversion, Ari mentions that the missionary Pangbrandr killed two or three men who had slandered him; this is given as the reason for his return for Norway. Ari's vague 
approximation may suggest that his sources are unreliable, or it may express anxiety about what he here leaves untold, in what Lieu calls a 'deliberate not remembering'. Later in the same chapter, Ari quotes two lines of verse spoken by Hjalti Skeggjason insulting the goddess Freyja - a scrap of poetry inserted out of context and chronological order to explain why Hjalti had previously been outlawed. These tiny glimpses of violent (or at least verbal) collison between the missionaries and pagan Icelanders threaten Ari's careful construction of the Icelanders' conversion as 'late and peaceful', distanced from the religious violence experienced elsewhere. Yet they are corroborated by the existence of skaldic stanzas dating to the conversion era, which testify to 'untold' stories of violent injury, insult and slander. ${ }^{45} \mathrm{Hjalti}$ certainly seems to have been involved in this, although his story survives only in small pieces. Some of the stories surrounding Pangbrandr's killings are imaginatively recuperated in later narratives of conversion, such as Kristni saga and Pangbrands páttr, and they are successfully incorporated into a traditional feud pattern in Njáls saga, with the addition of lively dialogue and heroic double killings. Ari's narrative proceeds by the denial of stories 'untold or repressed', deliberately 'not remembered'.

My main interest here, though, is not in these loose ends so much as in absences: in this case, the absence of the papar who allegedly left Iceland when the Northmen arrived: the absence of alternative Christianities. ${ }^{46}$ Even if the papar had no impact on the native population, it is widely recognized that several of the settlers Ari mentions would actually have come to Iceland via the British Isles, bringing Christianity with them. ${ }^{47}$ Ari himself claimed descent from one of the four main settlers he identifies, Auðr the Deep-Minded, and must have known that she came to Iceland via Ireland and the Hebrides, since he notes that she was married to Óleifr the White, the Norse king of Dublin, and traces his descent from her grandson, Óleifr feilan (the Irish nickname 'little wolf'). Yet Ari keeps silent about Auðr's potential familiarity with the Christianity of the British Isles, and records in his genealogy that the first Christian in his family was Eyjólfr, Auðr's great-great-grandson, who was baptized in his old age 'when Christianity came to Iceland' (p. 28).

Ari's silence about Irish Christianity is reproduced in Laxdela saga, which gives Auðr (there called Unnr) a grand pagan burial in a ship. It is tempting to read both these silences as deliberate repression in the interests of 'sameness and continuity' or 'denial of difference', especially in the context of alternative narratives that foreground Auðr's Christian faith. ${ }^{48}$ Both Landnámabók and Eiríks saga rauða 
record that she was a baptised Christian, and Landnámabók describes how she was buried, at her own request, i flœðarmáli ('below the mark of the high tide'), because she did not wish to lie in unconsecrated earth. Stefán Karlsson relates this to the tradition that all waters are consecrated by Christ's baptism in the Jordan, and notes that some Norwegian laws designate this tidal space, neither land nor sea, as suitable for the burial of unbaptized children; it is similar to the English practice of burying the dead under the eaves of the church, so that sanctified water would drip down on them. ${ }^{49}$ To remember Auðr's burial on the seashore is to situate her in a liminal space, a borderland, between pagan past and Christian future, between socio-political authority and divine agency, temporarily stranded or out of place. ${ }^{50}$ It is a space associated with sanctity: it is where St Nicholas falls asleep as a child with his lectionary on his lap, and where St Cuthbert's book is found when it washes ashore undamaged. ${ }^{51}$ In Eiríks saga rauða, moreover, burial on the seashore evokes the patristic figure of Christian life as voyage across the sea, which is later figured in the search for the paradisal Vínland and the final pilgrimage of Guðríðr (herself a descendent of one of Auðr's freed slaves, and a Christian before the conversion) to Rome. ${ }^{52}$ Auðr's burial on the seashore sets her apart from the social and legal structures of pagan Iceland; it constructs a new identity for her as a Christian peregrinus or 'pilgrim'.

There are many other examples of stories 'as yet untold' in Ari, connections that he does not make or perhaps deliberately suppresses between the Christianities of the settlement period and the legal conversion of Iceland. It has been suggested that Ari, like Bede before him, was hostile towards British Christianity as a competitor of the Roman Church or, which is more likely, that he downplayed the Christianity of the British Isles because of the continental Christianity of Gizurr's family. ${ }^{53}$ Later sagas certainly suggest that Hebridean Christianity could be perceived as suspect, most obviously in the case of Pórgunna in Eyrbyggja saga, a Hebridean who arrives from Dublin bringing a mysterious curse, which Ólafur Halldórsson has suggested may preserve a memory of Manx legends about the sea deity Manannán mac Lir. ${ }^{54}$ Yet it is also clear that Ari's decision about what to forget was ideologically driven: he could hardly present the Icelanders as a people with 'one law and one religion', if heathenisms and different varieties of Christianity had in fact coexisted from the start. Faced with this problem, Ari chose to ignore those memories that did not match his conversion narrative, to stick with the 'focality' of a single story. 
Nevertheless, some of these alternative stories or unofficial memories are imaginatively recuperated in later narratives about early Christianity in Iceland. I would like to look here at three stories in Landnámabók ('The Book of Settlements'), which was probably first compiled in the twelfth century, but survives only in later redactions. ${ }^{55}$ There are multiple versions of these stories, but I will concentrate on those in the redaction of Landnámabók in Hauksbók, an encyclopedic compilation assembled in 1302-19 by the Icelandic lawman Haukr Erlendsson. Haukr based his version of Landnámabók on the earlier version made by Sturla Pórðarson (died 1284), and he placed it in an anthology of other texts on history, geography and theology, that projects a catholic worldview. ${ }^{56}$ Rowe has argued that Haukr's purpose in producing this codex was to boost his power and authority in Norway; this gave him a vested interest in Irish Christianity, since he traced his descent from the Irish king Kjarvalr (Cerball). ${ }^{57}$ It also gave a marked clerical bent to Haukr's selection of texts, as he harnessed for his own purposes the considerable authority of the medieval Church: he follows his version of Landnámabók with Kristni saga ('The Story of the Conversion'), which claims to tell the story of 'hversu kristni kom á Ísland' ('how Christianity came to Iceland') from the arrival of the first missionaries in Iceland in 986 to the episcopates of Ísleifr and Gizurr. This incorporates Ari's narrative of conversion, but extends it back in time to cover earlier missions by Porvaldr and Friðrekr, Stefnir, and finally Pangbrandr. ${ }^{58}$ Yet, in contrast to Ari's strong sense of social and legal continuity between pre- and post-conversion Iceland, Haukr's narrative - from settlement in Landnámabók to conversion in Kristni saga - abounds in discontinuity, conflict and confrontation. What he remembers is an embattled and ascetic Christianity, a Christianity under siege on the margins of the world.

Haukr, like Ari, begins his book with an account of the papar in Iceland. In this, he sticks closely to the story told in Sturla's version of Landnámabók:

En áđr Ísland byggðisk af Nóregi, váru par peir menn, er Norðmenn kalla papa; peir váru menn kristnir, ok hyggja menn, at peir hafi verit vestan um haf, pví at fundusk eptir peim bœkr írskar, bjõllur ok baglar ok enn fleiri hlutir, peir er pat mátti skilja, at peir váru Vestmenn. Enn er ok pess getit á bókum enskum, at í pann tíma var farit milli landanna (pp. 31-32).

And before Iceland was settled from Norway, there were men here, whom the Northmen call papar; they were Christians, and people believe that they were from west over the sea, because Irish books, bells and staffs, and still more objects were left behind them, from which it could be seen that they were from 
the west. It is also mentioned in English books that there were journeys between the lands at that time.

There are some small, but significant, differences here from Ari's originary account. The papar are not identified as from Ireland only, but from the British Isles ('West over the sea') and there is no mention that they left when the Northmen arrived, although this may be implied by the objects 'left behind'. Instead, the allusion to 'journeys between the lands' (backed by the authority of 'English books') allows for the possibility of overlap, of blurring the distinction between the papar and settlers who came via Ireland, Scotland, and the Hebrides. Haukr's own addition is to specify locations for the objects found, linking them to local place-names, rather than to Iceland as a whole: 'Pat fannsk í Papey austr ok í Papýli' ('They were found in Papey in the East and in Papýli'). The 'books' and 'bells' in particular, become a symbolic focus in Haukr's account of the first Christian settler, Ørlygr Hrappsson.

Ørlygr, who settles in Kjalarnes in the South-East of Iceland, was fostered in the Hebrides by a Bishop Patrick, described as inn helgi ('the holy/the saint'), who has probably been confused, whether by accident or deliberation, with Patrick the patron saint of Ireland. Patrick gives Ørlygr wood for a church, a plenarium (probably a gospel book), an iron bell, a gold penny and consecrated earth to take with him to the new land. He instructs Ørlygr to build a church dedicated to St Columba (Kolumkilla) in a place where three mountains are visible from the sea, where he is to raise three stones. The presumably Trinitarian significance of these is Haukr's addition to the story in Sturlubók, where only two mountains are named. As Ørlygr nears Iceland, a storm blows up; he calls upon Bishop Patrick for help and lands safely, after promising to name the fjord after his patron: Patreksfjörðr. Haukr adds to this that his foster-brother Kollr calls on Pórr; they are separated in the storm and Kollr's ship is wrecked, although he and his crew survive. Later, as Ørlygr sails around the coast, the bell that Patrick gave him falls overboard; it is found in a pile of seaweed near to the place where Ørlygr settles and builds a church.

The 'sameness and continuity' that constitutes Christian identity here is not, as for Ari, coterminous with the socio-political order; it is the 'sameness and continuity' of the Christian supernatural, channelled through the relics of the saint. The virtus ('power' or 'virtue') of the saint is literally exported from the Hebrides in the consecrated earth and contact relics provided by Bishop Patrick; 'remembering' him as St Patrick thus carries theological weight, collapsing historical chronology into the 
timelessness of the liturgical commemoration of the saints. As Wellendorf has shown, Haukr's story about the bell is reminiscent of a miracle from the life of the Irish saint Declan, an older contemporary of St Patrick. ${ }^{59}$ Like Declan's bell, which is left on a rock and floats to the place of his resurrection, or the altar of the British saint Caaranog, which he casts into the sea to lead 'where God wished him to go', St Patrick's bell guides Ørlygr to the site preordained for his church. ${ }^{60}$ Through associating relics with local traditions and place-names, Haukr maps holy sites onto the Icelandic landscape, just as Heimslysing ('A Description of the World') later in the same codex measures geographical space by the shrines of saints. ${ }^{61}$ The objects that connect Ørlygr with the papar do not lie passively, waiting to be found; they play an active role in defining the religion of this local community. Haukr tells us that Ørlygr's descendents 'trúðu á Kolumkilla, pó at peir væri óskírðir' ('believed in Columba, although they were not baptised'). How long this local form of Christianity continues is not clear, but there is no sign of it in Kristni saga, when Stefnir Porgilsson arrives in Kjalarnes in 995/6 to convert it to Christianity. We are told that he meets with a poor reception, especially from his family, 'pví at allr lýðr var pá heiðinn á landi hér' ('because everyone in this land was then heathen'). ${ }^{62}$ Stefnir, like Ørlygr, is the descendent of a Hiberno-Norse Christian, Helgi bjóla, but no link is made to any inherited or local form of Christianity.

Haukr diverges from Ari here in the attention that he pays to Hebridean Christianity and to local religion in Kjalarnes; but he also contests Ari's emphasis on the religious neutrality or homogeneity of the pre-Christian period in Iceland. In his account, the Iceland of the settlers is religiously divided: Ørlygr is a Christian, but his foster-brother Kollr is a pagan, and the competition between the two faiths is vividly captured in the story of how Ørlygr prays successfully to Christ, while Kollr calls unsuccessfully on Pórr. This reads like a riposte to the comment in Sturlubók about the Hiberno-Norse Christian Helgi the Lean, who 'trúđi á Krist, en pó hét hann á Pór til sæfara ok harðræða' ('believed in Christ, but called on Pórr for sea journeys and difficulties'), to which Haukr adds rather cynically 'ok alls pess, er honum pótti mestu varða' ('and whatever else he thought mattered most'). It points towards the later scene in Kristni saga where Pangbrandr and the pagan poet Steinunn quarrel over whether Christ or Pórr has more power over the wind and waves, a debate commemorated in two skaldic stanzas, which declare triumphantly that: 'Hlífði ei 
Kristr' ('Christ gave no protection'). ${ }^{63}$ Unlike Ari, Haukr insists that religious difference and competition characterise the religion of the settlement period.

This opposition between paganism and Christianity also colours Haukr's story about Patrick's bell. As Wellendorf has illustrated, there is a close parallel here with pagan rituals of settlement as described in Landnámabók and elsewhere: Ingólfr throws his high-seat pillars overboard and determines to settle in the place where they land, as do some other settlers, including Pórólfr Mostrarskeggi, whose pillars are engraved with the image of Pórr. Wellendorf argues that we are dealing here with the same motif: successful settlement depends on the cooperation of spiritual powers, whether these are pagan or Christian. ${ }^{64}$ What matters is 'piety and religious/cultic behaviour' regardless of what religion one has. This might be described as a typological interpretation, by which the old comes to prefigure the new. The problem is that, in Haukr's story, it does matter who one prays to: it is Ørlygr, calling on Bishop Patrick, who reaches land safely, while Kollr receives no help from Pórr. This story corrects those in which Pórr directs settlers where to land or crushes the ships of Christian missionaries. Haukr is quite conscious here that, in Nock's terms, 'the old is wrong' and the 'new is right': there are clear moral choices to be made.

Haukr gives no more details about Christianity in Kjalarnes, but Kjalnesinga saga, dating also to the early fourteenth century, picks up where Landnámabók leaves off. It gives a vivid imaginative depiction of how this area of Iceland, after settlement, was riven by competing faith-systems: how churches and temples stood in adjoining districts, and how Irish Christianity coexisted with Norse paganism and benevolent sorcery. The consequence is precisely the religious conflict that Ari tries to hard to deny: Búi, son of the Irish Christian Andríðr, is outlawed 'um rangan átrúnað' ('for having the wrong faith'), and he burns down a pagan temple belonging to Helgi bjóla (now a Norse pagan) while his son is praying inside. ${ }^{65}$ This story has little or nothing to do with historical fact: Helgi bjóla was, at least according to Landnámabók, a baptized Christian, and his nickname certainly suggests mixed Irish descent. Rather, the saga projects backwards in time the religious struggles in Kjalarnes during Stefnir's mission: Stefnir too is prosecuted for being a Christian, after burning down pagan temples and shrines. ${ }^{66}$ In Kristni saga and in Stefnis páttr, this is about extremism and persecution, which results first in Stefnir's outlawry and eventually in his death. In Kjalnesinga saga, as Cook has shown, it has become a fiction about 'integration' and 'assimilation' between early Norse and Irish settlers. ${ }^{67}$ Búi, aspects 
of whose story may be based on the Irish hero Cúchulainn, returns from outlawry to marry Helga, the heathen daughter of his enemy. ${ }^{68}$ When he dies, his religion dies out too. We are told that he is buried in the church that Ørlygr had built, but to which 'engan maðr gaf gaum' ('nobody paid attention'). The saga ends where Ari's history begins, with the sacred objects the papar left behind:

Sú in sama járnklukka hekk pá fyrir kirkjunni á Esjubergi, er Árni biskup réð fyrir stað, Porláksson, ok Nikulás Pétrsson bjó at Hofi, ok var pá slitin af ryði. Árni biskup lét ok pann sama plenarium fara suðr í Skálholt ok lét búa ok lima öll blöđin í kjölinn, ok er írskt letr á (pp. 43-44).

The same iron bell hung in the church at Esjuberg when Bishop Árni Porláksson was in charge of the see and Nikulás Pétrsson lived at Hof, and it was then damaged by rust. Bishop Árni had the same plenarium sent south to Skálholt and had all the pages repaired and glued to the binding, and there is Irish writing in it.

The neglected church is a poignant reminder of the vanished Christianity of the Irish settlers: all that survives into the present of the audience is a rusty bell and an illegible book. The saga engages imaginatively with alternative (perhaps local) stories about Irish Christianity, but then cuts back to the official narrative line.

In these stories, Ari's allusion to Irish books and bells becomes an imaginative prompt for alternative narratives of how Christianity first came to Iceland; through remembering differently, they challenge the 'focality' of Ari's brief account and suggest the existence of other, local, Christianities. Yet they all end officially with Christianity dying out before the arrival of the first Christian missionary. On the same hills where Auðr the Deep-Minded raised crosses, her descendents set up pagan shrines and sacrifice: 'Trúðu peir pví, at peir dœi í hólana' ('They believed that they would enter the hills when they died'). ${ }^{69}$ Helgi the Lean calls his farmstead after Christ (Kristnes), but his son Ingjaldr raises a temple to Freyr at Pverá, and his greatgrandson Víga-Glúmr turns from the worship of Freyr to Óðinn, before a deathbed conversion to Christianity at the hands of Bishop Kolr. ${ }^{70}$ There may be "continuity of religious observance' here, but there is discontinuity in terms of beliefs. ${ }^{71}$ At the end of his Landnámabók, Haukr concludes in line with Sturlubók:

Nökkurir landnámsmenn hafi skírðir verit, peir er byggt hafa Ísland, flestir peir, er kómu vestan um haf [...] En pat gekk óvíða í ættir, pví at synir peira sumra reistu hof ok blótuðu, en land var alheiðit nær hundraði vetra (p. 396). 
Some of the men who settled Iceland were baptised, most of those who came from west over the sea [...] But it did not last among their descendants, because the sons of some of them raised temples and sacrificed, and the land was completely heathen for nearly a hundred years.

It is as if the presence of Irish and Hebridean Christianity has to be discontinued or at least interrupted in order for the official story of the conversion to commence.

There are a couple of stories, however, in which Irish Christianity in Iceland is not altogether discontinued or denied. The first is the story of Ásólfr alskikk, which Haukr expands significantly from Sturlubók, as he does in the case of Ørlygr. Ásólfr comes to Iceland from Ireland with twelve companions (like the Irish céli Dé); he tries to settle in three different places, but is repeatedly driven away by the heathen inhabitants because of his miraculous catches of fish. As Jesch has commented, this is a characteristically Irish miracle, a detail that Haukr, with his Irish interests, did not miss. ${ }^{72}$ It is perhaps why he emphasizes the Irish identity of Ásólfr and his companions, simplifying their mixed Irish-Norse descent. Haukr's longest addition to Sturlubók is what happens after Ásólfr's death: he tells how, over a century afterwards, a servant woman is wiping her feet on the mound of grass over his grave. Ásólfr, much put out, appears to her in a dream and commands her to inform the local magnate Halldórr of his presence. Halldórr, however, 'gaf ekki gaum at' ('paid no attention'), commenting that he does not care for women's dreams. Ásólfr then makes a second appearance, this time to a monk left behind by one of the early missionary bishops in Iceland, Hróđólfr. The monk buys the land, finds Ásólfr's bones and exhumes them. Ásólfr then appears in a third dream, this time directly to Halldórr, and orders him to buy back the bones immediately or he will put out both his eyes. This time, Halldórr reacts at once, and sends his son Illugi to Norway to get wood, intending to build a church over Ásólfr's grave. Caught in a storm at sea, Illugi throws the wood overboard, telling it to come to land 'where Ásólfr wishes'. It drifts straight to the site of his cell, where a church is built and dedicated to Kolumkille.

This story has a number of points in common with that of Ørlygr: early conflict between pagans and Christians, the supernatural guidance of the church wood (based this time on a miracle of St Giles), and the dedication to Kolumkille. ${ }^{73}$ But it is much more obviously indebted to hagiography in the fishing miracles and the translatio that identify Ásólfr as an incipient or potential saint. ${ }^{74}$ In his peregrinations around Iceland (so different from the stabilitas of Benedictine monasticism), we catch 
a glimpse of the papar on peregrinatio pro amore Dei ('pilgrimage for the love of God'): Iceland functions less as Ari's 'promised land' than as a wilderness or heremum in oceanum ('desert in the ocean'). ${ }^{75}$ Ásólfr is driven from place to place by the hostility of the local inhabitants, but his presence in this wasteland renews it with paradisal abundance in the miraculous catches of fish. Perhaps there is even an incipient idea here of Iceland, like Ireland, as the 'isle of saints': Ásólfr creates, wherever he goes, tiny 'islands' of sanctity, where he lives in harmony with the natural world. The explanation in Sturlubók that he 'vildi ekki eiga við heiðna menn' ('did not wish to have dealings with heathens'), and that 'hann lézk ekki vilja vera hjá öðrum mönnum' ('he said that he did not wish to be with other people') echoes Ari's comment that the papar 'vildu eigi vesa hér við heiðna menn' ('did not wish to be here with heathens'). This story perhaps originated, Jesch has suggested, at the end of the twelfth century, when there was considerable interest in local sanctity: saints were an important way, on the periphery of the world, of consolidating one's Christian identity, constructing a new Christian centre. ${ }^{76}$ With Ásólfr, Iceland enters into a new and universal story: the master narrative of the communion of saints.

Particularly interesting is the way this story is presented as one that has been forgotten or repressed; the culpable neglect of Irish Christianity neatly captured in the image of the servant using the mound above Ásólfr's grave as a doormat to wipe her muddy shoes. It takes three, increasingly vociferous, appearances on the part of Ásólfr to reawaken the memory of his saintly presence in the land; he succeeds only in the face of difficulty and disruption in getting his story told. The comment that Halldórr 'gaf ekki gaum' ('paid no attention') echoes closely what was said of Ørlygr's church in Kjarlarnes, to which 'gaf pá engi maðr gaum' ('nobody then paid attention'). The narrative that emerges from Ásólfr's story is one of multiple Christianities: the asceticism of the Irish papar, the Anglo-Norman missions to Norway and Iceland (Hróðólfr was a kinsman of Edward the Confessor and died in 1052 as abbot of Abingdon monastery), the economics of importing church wood from Norway, the universalism of the Christian saint. ${ }^{77}$ It is worth recalling at this point Szpiech's concept of the convert as 'chronotope', embodying a distinctively Christian configuration of time and space: Ásólfr embodies the intersection between the early eremitism of the papar and the later history of Christianity, between the local church in Innri-Hólmr and the universal Church, of which the saint is a limb. 
At the same time, Clunies Ross has argued that Haukr shifts the emphasis in this story from the ascetic Christianity associated with the Irish settlers to a more recognizably Icelandic version of sanctity, in which religious authority is inherited from one's ancestors. ${ }^{78}$ She points out that Haukr omits the comments that Ásólfr 'did not wish' to live with heathens, and has him marry and produce descendants who are allied to important families, such as the Kjalleklingar. Like his kinsman and fellow settler, Jörundr inn kristni ('the Christian'), Ásólfr does not become a hermit until 'old age'. Indeed, his appearance to Halldórr, son of the chieftain Illugi inn rauði ('the Red') reincorporates the desert saint into the social and political structures of Iceland: Illugi is listed in Kristni saga among 'stœrstir höfðingjar á landinu' ('the greatest chieftains in the land') when the first missionary arrives in Iceland. ${ }^{79}$

Haukr's final story is less obviously hagiographic, but it makes the most explicit link so far between Ari's papar and the later history of the Christian missions. Ketill inn fíflski ('the Foolish') travels to Iceland from the Hebrides and is described as 'vel kristinn' ('a good Christian'). Haukr tells us that: 'Ketill bjó í Kirkjubœ; par höfðu áðr setit papar, ok eigi máttu par heiðnir menn búa ('Ketill lived in Kirkjubœr; the papar had previously dwelt there, and heathens could not live there'). Again, there is an echo here of Ari's explanation that the papar 'did not wish to be here with heathens'. Clunies Ross suggests that Ketill's nickname shows 'an attitude of tolerant contempt' on the part of his heathen neighbours, but it may also preserve a memory of extreme Irish eremitism, following in the tradition of the 'holy fool' ${ }^{80}$ This is all we hear about Ketill himself, but the place where he settles, Kirkjubœr (where a convent was founded in 1186), comes up just three chapters later. ${ }^{81}$ We are told that Ketill's heathen neighbour Hildir tries to take over the farmstead after Ketill's death:

Hildir vildi fœra bú sitt í Kirkjubœ eptir Ketil ok hugði, at par mundi heiðinn maðr mega búa. En er hann kom nær at túngarði, varð hann bráðdauðr (p. 326)

Hildir wished to move his household to Kirkjubœr after Ketill's death, and thought that a heathen would be able to live there. But when he came up to the fence around the home meadow, he suddenly dropped dead.

The fence here forms a boundary between heathen and Christian territory; it encloses and protects a tiny 'island' of sanctity in the middle of a pagan wilderness. It is a story that resists those in which Christian territory is reused by heathens; such as Auðr's descendants sacrificing on the hills where she had raised crosses (itself a neat reversal 
of Pope Gregory's instructions to build churches on the site of pagan temples). ${ }^{82}$ Hildir is violently punished for his presumption in thinking that he can cross into the sacred space of this early Hiberno-Norse Christian settlement.

No more is said about Kirkjubœr in Landnámabók, but another story is recorded in Kristni saga that reaffirms the sanctity of this place:

Pá kaupa heiðnir menn at peim manni er Galdra-Héðinn hét at hann felldi jörð undir Pangbrandi. Pann dag er peir riði ór Kirkjubœ frá Surts Ásbjarnarsonar, Ketilssonar ins fíflska - peir váru allir skírðir langfeðgar - pá fell hestr Pangbrands í jörð niðr, en hann hljóp af baki ok stóð á bakkanum heill (p. 19).

The heathens paid a man called Galdra-Héðinn to make the ground fall away beneath Pangbrandr. On the day they rode away from Kirkjubœr from the home of Surtr, son of Ásbjõrn, son of Ketill the Foolish - all his forebears on the father's side were baptized - then Pangbrandr's horse fell down into the ground, but he jumped off its back and stood on the brink unharmed.

Hermann Pálsson has connected this with a frequent motif in Irish saints' lives, in which the earth swallows up evildoers at the command of the saint. ${ }^{83}$ Yet it is also precisely the inverse of the story told about Hildir: in one, a pagan drops dead as he attempts to enter Christian territory, in the other, a Christian comes close to death as he crosses from Christian to pagan space. To cross the boundary of the farmstead is to move from sacred to profane; beyond the sanctuary at Kirkjubœr, the landscape is a wilderness that cannot be trusted, but opens unpredictably onto the abyss. In Njáls saga we are told that the earth 'swallowed' the horse, like the medieval hell-mouth itself. The topography of this scene, it has been argued, is distinctively Icelandic, suggesting a volcanic cavity under the sand. ${ }^{84}$ But it is also the topography of Christian eschatology, 'the great plot that joins Apocalypse and Genesis'.

Kirkjubœr stands here as a small stronghold of Christianity, its power residing in the unbroken line of baptised Christians that have lived there from the papar on. This unbroken continuity of Christian observance not only stretches back to the settlement and beyond, but also forwards into the later Christian times. By the midtwelfth century, Kirkjubœr was a major ecclesiastical centre, where St Porlákr spent six years as district priest. It later became a convent, in which both daughters of the chieftain Gizurr Hallsson were nuns. In Porláks saga helga, the saint affirms his high opinion as to the gafa or gipta ('luck' or 'charisma') of the place: 'Hann hefði aldregi sínu ráđi jafn vel unat sem pá sex vetr er hann var í Kirkjubœr' ('He had never been happier with his lot than during the six years he spent at Kirkjubœr'). ${ }^{85}$ The fragments 
of this story, once pieced together, oppose the official assessment in Landnámabók that 'the land was completely heathen for nearly one hundred years'.

What we see, in these various accounts of early Christianity in Iceland, is an imaginative recuperation of 'as yet untold stories', stories based on a variety of local Christianities that resist the suppression - or at least the absence - in Ari of any material link between Irish eremitism and the later conversion to Christianity. It is difficult, of course, to say how many of these stories Ari may have known, since most are recorded in much later sources. Some may well go back to the settlement period, growing up perhaps around unusual place-names (like Patreksfjörðr) or material relics (like bells) - objects which are neglected and lost, but then found and reclaimed in much the same way as these stories themselves. The incorporation of motifs from Irish mythology and British saints' lives certainly suggests contact with the British Isles, although it is difficult to say exactly when this may have taken place. Other stories, like that of Ásólfr, may have arisen in connection with the native hagiography being produced at the turn of the twelfth century, as Iceland 'entered into' the communion of saints through the appropriation of the discourse of sanctity. They figure Iceland as a wilderness in which desert saints like Ásólfr create tiny 'islands' of sanctity, or in which a place like Kirkjubœr, once a locus of peregrinatio on the periphery of the world, can become a major centre of ecclesiastical activity. Still other stories may reflect the idiosyncratic interests of individuals like Haukr, who traced his descent from an Irish king and in whose interests it was to stress the internationalism of Icelandic Christianity. However they may have arisen, these narratives, in contrast to Ari's emphasis on 'continuity and sameness', are characterised by conflict and confrontation, discontinuity or difference; they engage creatively with alternative accounts of 'how Christianity came to Iceland'. Ásólfr's struggle to get a hearing for himself mirrors the imaginative effort required to unearth these local stories about early Christians from beneath the official narrative line. The 'focality' of telling a single story served Ari well, but he knew - one suspects - that there was more than one way to tell this story. Beyond Ari's 'little book' lies a multiplicity of 'untold and repressed stories' to be recuperated by the literary imagination.

\footnotetext{
${ }^{1}$ James Muldoon, 'Introduction: The Conversion of Europe', in Varieties of Religious Conversion in the Middle Ages, ed. James Muldoon (Gainesville: University Press of Florida, 1997), p. 1.
} 
${ }^{2}$ Frederick J. Gaiser, ‘A Biblical Theology of Conversion', in Handbook of Religious Conversion, ed. H. Newton Malony and Samuel Southard (Birmingham, Alabama: Religious Education Press, 1992), pp. 93-95. The Hebrew root is šûb ('to turn back, to return'); the Greek New Testament uses the terms epistrepho ('to turn, turn around, turn back'), metamelomai ('to change one's mind, regret, repent') and metanoē ('to change one's mind, repent, be converted'). On Augustine's use of words with the root 'vert', see Kenneth Burke, The Rhetoric of Religion: Studies in logology (Berkeley: University of California, 1970), pp. 82-83.

${ }^{3}$ Arthur Darby Nock, Conversion: The Old and the New in Religion from Alexander the Great to Augustine of Hippo (Oxford: Clarendon Press, 1933), p. 7.

${ }^{4}$ See, for example, Ramsay MacMullen, Christianizing the Roman Empire (AD 100400) (New Haven: Yale University Press, 1984), pp. 4-5; Robert W. Hefner, 'Introduction: World-Building and the Rationality of Conversion' in Conversion to Christianity: Historical and Anthropological Perspectives on a Great Transformation (Berkeley and Los Angeles: 1993), pp. 17-18; James Russell, The Germanization of Early Medieval Christianity: a socio-historical approach to religious transformation (New York and Oxford: Oxford University Press, 1994), pp. 28-30; Muldoon, 'Introduction: The Conversion of Europe', pp. 3-5.

${ }^{5}$ Gaiser, 'Biblical Theology', p. 104; for 'acculturation' and 'christianization', see The Christianization of Scandinavia, ed. Birgit Sawyer, Peter Sawyer and Ian Wood, [PAGES] (Alingsås: Viktoria Bokförlag, 1987); Nora Berend, Christianization and the Rise of Christian Monarchy: Scandinavia, Central Europe and the Rus', c. 9001200 (Cambridge: Cambridge University Press, 2007), pp. 3-4; Anders Winroth, The Conversion of Scandinavia: Vikings, Merchants, and Missionaries in the Remaking of Northern Europe (New Haven: Yale University Press, 2012), pp. 103-104; Marc David Baer, 'History and Religious Conversion', in The Oxford Handbook of Religious Conversion, ed. Lewis R. Rambo and Charles E. Farhadian (New York: Oxford University Press, 2014), pp. 26-28. Peter Foote makes a useful distinction between 'moment' and 'period' in 'Historical Studies: conversion moment and conversion period', in Viking Revaluations: Viking Society Centenary Symposium 1992, ed. Anthony Faulkes and Richard Perkins (London: Viking Society for Northern Research, 1992), pp. 137-44.

${ }^{6}$ Karl Morrison, Understanding Conversion (Charlottesville and London: University Press of Virginia, 1992), p. 7 and Conversion and Text: the cases of Augustine of Hippo, Herman-Judah and Constantine Tsatisos (Charlottesville: University Press of Virginia, 1992), pp. xii.

${ }^{7}$ Lewis Rambo, Understanding Religious Conversion (New Haven and London: Yale University Press, 1993), p. 5 and 'Introduction', in Handbook of Religious

Conversion, pp. 5-6. For a recent attempt to apply Rambo's stages of conversion to Old Icelandic narratives of conversion, see Christopher Abrams, 'Modeling Religious Experience in Old Norse Conversion Narratives: the cases of Óláfr Tryggvason and Hallfreðr vandræðaskáld', Speculum 90 (2015), pp. 114-57.

${ }^{8}$ On the historical value of conversion narratives, see Richard Fletcher, The Conversion of Europe: From Paganism to Christianity (London: HarperCollins, 1997), p. 12; Winroth, The Conversion of Scandinavia, pp. 121-22.

${ }^{9}$ Morrison, Understanding Conversion, pp. 2-4; Conversion and Text, pp. vii, xii.

${ }^{10}$ Morrison, Understanding Conversion, p. 6; Conversion and Text, pp. xii-xiii. See also Bernard of Clairvaux, 'On Conversion', in Bernard of Clairvaux: Selected 
Works, trans. Gillian R. Evans (New York: Paulist Press, 1987), pp. 66-68 ('So the conversion of souls is clearly the work of the divine voice, not of any human voice'). ${ }^{11}$ Bruce Hindmarsh, 'Religious Conversion as Narrative and Autobiography', in Handbook of Religious Conversion, p. 345.

${ }^{12}$ Paula Fredriksen, 'Paul and Augustine: Conversion Narratives, Orthodox Narratives, Orthodox Traditions, and the Retrospective Self', Journal of Theological Studies 37 (1986), 33.

${ }^{13}$ George Stroup, The Promise of Narrative Theology (London: SCM, 1984), p. 79; Ryan Szpiech, Conversion and Narrative: Reading and Religious Authority in Medieval Polemic (Philadelphia: University of Penn State Press, 2012), p. 40.

${ }^{14}$ Szpiech, Conversion and Narrative, pp. 23, 47, 49. On the relationship of conversion to allegorical exegesis, see further Lynn M. Poland, 'Augustine, Allegory and Conversion', Literature and Theology 2 (1988), 40. The expression 'conversion by the book' is taken from Frederick H. Russell, 'Augustine: Conversion by the Book', in Varieties of Religious Conversion, pp. 13-30.

${ }^{15}$ Peter G. Stromberg, 'The Role of Language in Religious Conversion', in Handbook of Religious Conversion, p. 120.

${ }^{16}$ Paul Ricœur, Time and Narrative, 3 vols, trans. Kathleen McLaughlin and David Pellauer (Chicago: University of Chicago Press, 1984-88), II, 23.

${ }^{17}$ Szpiech, Conversion and Narrative, pp. 21-22.

${ }^{18}$ The phrase 'universe of discourse' is borrowed from George Herbert Mead, Mind, Self, and Society: from the Standpoint of a Social Behaviourist (Chicago: Chicago University Press, 1934), p. 89; it is used by David A. Snow and Richard Machalek, 'The Convert as Social Type', in Sociological Theory, ed. Randall Collins (San Francisco: Jossey Bass, 1983), pp. 265-66 and 'The Sociology of Conversion', Annual Review of Sociology 10 (1984), 170-173; Clifford Staples and Armand L. Mauss, 'Conversion or Commitment? A Reassessment of the Snow and Machalek Approach to the Study of Conversion', Journal for the Scientific Study of Religion 26 (1987), 133-47.

${ }^{19}$ Rambo, Understanding Conversion, pp. 120-37; 'The Psychology of Conversion', pp. 170-73; Stromberg, 'Role of Language', pp. 122-24; see also Stroup, Narrative Theology, who describes this point of contact in terms of 'collision' rather than 'impression' (p. 95).

${ }^{20}$ Rambo, 'The Psychology of Conversion', p. 179.

${ }^{21}$ For the suggestion that 'converting' is a better term than 'static' conversion, see Rambo, Understanding Religious Conversion, p. 7.

${ }^{22}$ Szpiech, Conversion and Narrative, p. 24.

${ }^{23}$ Judith Lieu, Christian Identity in the Jewish and Graeco-Roman World (Oxford: Oxford University Press, 2004), p. 312.

${ }^{24}$ Jacques Le Goff, History and Memory, trans. Stephen Rendall and Elizabeth Claman (New York: Columbia University Press, 1992), p. 68; Szpiech, Conversion and Narrative, p. 6.

${ }^{25}$ For the importance of continuity to national identity, see John R. Gillis, 'Memory and Identity: The History of a Relationship', in Commemorations: The Politics of National Identity, ed. John R. Gillis (Princeton: Princeton University Press, 1994), p. 3; Lieu, Christian Identity, p. 62; for the tension between sameness and discontinuity in narratives of conversion, see Gaiser, 'Biblical Theology of Conversion', p. 105, Stromberg, 'Role of Language', p. 124. On the relationship between religious and national identity, see Adrian Hastings, The Construction of Nationhood: Ethnicity, 
Religion and Nationalism (Cambridge: Cambridge University Press, 1997), pp. 18598; and for the interplay between universalism and nationalism or particularism, see Hans-Dieter Metzgen, 'Introduction', in Religious Thinking and National Identity (Berlin: Philo, 2000), p. 13; Lieu, Christian Identity, pp. 20-21; George Tugène, 'L'histoire "ecclésiastique" du people anglais: Réflexions sur le particularisme et l'universalisme chez Bède', Recherches Augustiniennes XVII (1982), 129-72. ${ }^{26}$ Lieu, Christian Identity, p. 64; Szpiech, Conversion and Narrative, p. 17. On 'contest', 'struggle' and 'annihilation', see Gillis, 'Memory and Identity', p. 4 and Nicholas Brookes, Bede and the English (Jarrow: St Paul's Church, 1999), p. 5. For a discussion of memory, 'the interplay between remembering and forgetting', and 'competing memories' in the sagas, see Pernille Hermann, 'Founding Narratives and the Representation of Memory in Saga Narrative', Arv 66 (2010), 69-87.

${ }^{27}$ Ricœur, Time and Narrative, I, 74.

${ }^{28}$ On election, see Anthony D. Smith, Myths and Memories of the Nation (Oxford: Oxford University Press, 1999), pp. 130-53; Mary Garrison, 'The Franks as the new Israel? Education for an identity from Pippin to Charlemagne', in The Uses of the Past in the Early Middle Ages, ed. Yitzhak Hen and Matthew Innes (Cambridge: Cambridge University Press, 2000), pp. 114-17 and Mary Garrison, 'Divine Election for Nations - A Difficult Rhetoric for Medieval Scholars', in The Making of Christian Myths in the Periphery of Latin Christendom (c. 1000-1300), ed. Lars Boje Mortensen (Copenhagen: Museum Tusculanum Press, 2006), pp. 276-77. Bede's rhetoric of 'election' is discussed by Patrick Wormald, 'The Venerable Bede and the Church of the English, in The English Religious Tradition and the Genius of Anglicanism, ed. Geoffrey Rowell (Wantage: Ikon, 1992), pp. 207-28; Sarah Foote, 'The Making of Angelcynn: English Identity before the Norman Conquest', Transactions of the Royal Historical Society, $6^{\text {th }}$ Series, VI (1996), pp. 38-41; aspects of this are contested by George Molyneaux, 'The Old English Bede: English Ideology or Christian Instruction', English Historical Review CXXIV/511 (2009), 1289-323.

${ }^{29}$ Jennifer O'Reilly, 'Islands and Idols at the ends of the Earth: Exegesis and Conversion in Bede's Historia Ecclesiastica', in Bede le Vénérable entre tradition et postérité, ed. Stéphane Lebecq, Michel Perrin and Olivier Szerwiniack (Villeneuve d'Ascq: CEGES, Université Charles-de-Gaulle, 2005), pp. 119-145.

${ }^{30}$ Augustine, Expositions of the Psalms, IV, trans. Maria Boulding, ed. John E. Rotella (Hyde Park, NY: New City Press, 2002), p. 191; Donald K. Fry, 'The Art of Bede: Edwin's Council', in Saints, Scholars and Heroes: Studies in Medieval Culture, 2 vols, ed. Margot H. King and Wesley M. Stevens (Collegeville, Minn: Hill Monastic Manuscript Library, 1979), I, 197-207.

${ }^{31}$ Julia Barrow, 'How Coifi pierced Christ's side: A Re-Examination of Bede's Ecclesiastical History', Journal of Ecclesiastical History 62.4 (2011), 693-06.

${ }^{32}$ Fredriksen, 'Paul and Augustine', p. 24.

${ }^{33}$ Poland, 'Augustine, Allegory and Conversion', pp. 37-48.

${ }^{34}$ For the interpretation of this story, see Sharon Rowley, 'Reassessing Exegetical Interpretations of Bede's Historia Ecclesiastica Gentis Anglorum', in Literature and Theology 17 (2003), 227-43 and 'Bede in later Anglo-Saxon England', in The Cambridge Companion to Bede, ed. Scott DeGregorio (Cambridge: Cambridge University Press, 2010), pp. 222-23.

${ }^{35}$ Barrow, 'How Coifi pierced Christ's side', p. 700; Rowley, 'Reassessing Exegetical Interpretations', p. 234. 
${ }^{36}$ Íslendingabók, Kristni saga. The Book of the Icelanders, The Story of the

Conversion, trans. Siân Grønlie, Text Series XVIII (London: Viking Society for

Northern Research, 2006), pp. xiii-xiv, xix-xx.

${ }^{37}$ Íslendingabók, Kristni saga, pp. xiv-xxviii; Siân Grønlie, 'From Bede to Ari:

Extending the Boundaries of Christendom', Qucestio 2 (2001), 27-42.

${ }^{38}$ Ari's account is endorsed by Dicuil, Liber de mensura orbis terrae, ed. James J.

Tierney with Ludwig Bieler (Dublin: Dublin Institue for Advances Study, 1967), pp.

75-77; Bedae venerabilis opera. Pars 2, Opera exegetica, vol. 1, ed. David Hurst (Turnhout: Brepols, 1962), p. 317. On the papar, see further Gillian Fellows-

Hermann, 'Language Contact in Iceland: the evidence of the names', Language

Contact across the North Atlantic, ed. P. Sture Ureland and Iain Clarkson (Tübingen:

Niemeyer, 1997), pp. 116-23; Hermann Pálsson, Keltar á Íslandi (Reykjavík: Hið

íslenzka fornritafélag, 1997), pp. 30-46; Jónas Kristjánsson, 'Ireland and the Irish in

Icelandic Tradition', in Ireland and Scandinavia in the Early Viking Age, ed. Howard

B. Clarke, Máire Ní Mhaonaigh and Raghnall Ó Floinn (Dublin: Four Courts Press, 1998), pp. 260-62; Christopher D. Morris, 'From Birsay to Brattahlíð: Recent

Perspectives on Norse Christianity in Orkney, Shetland, and the North Atlantic

Region', Scandinavia and Europe 800-1300: Conflict, Contact and Coexistence, ed.

Jonathan Adams and Katherine Holman (Turnhout, 2004), pp. 177-95; Margaret

Cormack, 'Irish and Armenian Ecclesiastics in Medieval Iceland', in West over Sea:

Studies in Scandinavian Sea-borne Expansion and Settlement, ed. Beverley Ballin

Smith, Simon Taylor, and Gareth Williams (Leiden: Brill, 2007), pp. 227-34.

${ }^{39}$ Margaret Clunies Ross, 'Textual Territory: the Regional and Genealogical Dynamic of Medieval Iceland Literary Production', New Medieval Literatures 1 (1997), 21-22;

John Lindow, 'Íslendingabók and Myth', Scandinavian Studies 69 (1997), 456;

Pernille Hermann, 'Íslendingabók and History', in Reflections on Old Norse Myths, ed. Pernille Hermann, Jens Peter Schjødt and Rasmus Tranum Kristensen, Studies in

Viking and Medieval Scandinavia 1 (Turnhout: Brepols, 2007), pp. 25-27.

${ }^{40}$ Biskupa sögur I, ed. Sigurgeir Steingrímsson, Ólafur Halldórsson and Peter Foote, Íslensk fornrit 15 (Reykjavík: Hið íslenzka fornritafélag, 2003) pp. 7-8, 61-68, 125.

${ }^{41}$ Biskupa sögur I, 105, 157, 162.

${ }^{42}$ Adomnan's Life of Columba, ed. and trans. Alan Orr Anderson and Marjorie Ogilvie Anderson (Oxford: Clarendon Press, 1991), ii. 8-9, pp. 104-107; Symeon of Durham, A history of the Church at Durham, trans. Joseph Stevenson (Felinfach: Llanerch, 1993), pp. 660-63

${ }^{43}$ Jón Hnefill Aðalsteinsson, Under the Cloak: The Acceptance of Christianity in Iceland with Particular Reference to the Religious Attitudes Prevailing at the Time (Stockholm, 1978), pp. 103-23; a similar view was expressed by Jan de Vries, 'Ein Problem in der Bekehrungsgeschichte Islands', Zeitschrift für deutsches Altertum 89 (1958-59), 75-82. For biblical parallels, see 1 Kings 17.13, Ezra 9.3-5.

${ }^{44}$ Heilagra manna s $\phi g u r, \mathrm{I}, 555$. On the possible Christian significance of the cloak and other instances, see further John Lindow, 'Akkerisfrakki', Journal of English and Germanic Philology 106.1 (2007), 64-80.

${ }^{45}$ Siân Grønlie, 'Preaching, Insult and Wordplay in the Old Icelandic kristniboðspaettir', Journal of English and Germanic Philology 103.4 (2004), 457-74. ${ }^{46}$ Jónas Gíslason, 'Acceptance of Christianity in Iceland in the Year 1000', in Old Norse and Finnish Religions and Cultic Place-Names, ed. Tore Ahlbäck (Stockholm: Almqvist \& Wiksell, 1987), pp. 223-55. 
${ }^{47}$ Gísli Sigurðsson, Gaelic Influence in Iceland: Historical and Literary Contacts: A Survey of Research (Reykjavík: Bókaútgáfa Menningarsjóđs, 1988). On Irish Christianity in Iceland, see further Helgi Guðmundsson, Um haf innan: Vestranir menn og íslensk menning á miðöldum (Reykjavík: Háskólaútgáfan, 1997); Hermann Pálsson Keltar á Íslandi; Jenny Jochens, 'Late and peaceful: Iceland's conversion through arbitration in 1000', Speculum 74 (1999), 632-43.

${ }^{48}$ Preben Meulengracht Sørensen, 'Norge og Irland i Laxdola saga', in At fortalle Historien. Telling History (Trieste: Parnasso, 2001), pp. 71-80; Andrew Hamer Njáls saga and its Christian Background. A Study of Narrative Method (Leuven, Paris, Walpole MA: Peeters, 2015), p. 47.

${ }^{49}$ Stefán Karlsson, 'Greftun Auðar djúpúðga', in Minjar ok Menntir: Afmaelisrit helgað Kristjáni Eldjárn, ed. Guðni Kolbeinsson (Reykjavík: Bókaútgáfa Menningarsjóðs, 1976) pp. 481-88; Christopher Daniell, Death and Burial in Medieval England, 1066-1550 (London: Routledge, 1997), p. 92.

${ }^{50}$ On the significance of the shore, see Barry Cunliffe, Facing the Ocean: The Atlantic and its Peoples (Oxford: Oxford University Press, 2001), p. 9; Daniell, Death and Burial in Medieval England, p. 91; Catherine Clarke, 'Edges and Otherworlds: Imagining Tidal Spaces in Early Medieval Britain', in The Sea and Englishness in the Middle Ages, ed. Sebastian Sobecki (Cambridge: Brewer, 2011), pp. 89-94.

${ }^{51}$ Symeon, A History of the Church of Durham, p. 63; Heilagra manna s $\phi g u r$. Fortallinger og legender om hellige mand og kvinder, ed. Carl R. Unger, 2 vols (Christiania: Bentzen, 1877), II, 65.

${ }^{52}$ Sverrir Tómasson, 'Ferðir pessa heims og annars. Paradís - ódáins akur - Vínland í íslenskum ferðalýsingum miðalda', Gripla 12 (2001), 23-40. On the hagiographic background to Eiríks saga, see Teresa Paróli, 'Bishops and Explorers: On the Structure of the Vinland Sagas', in Sagnaping helgað Jónasi Kristjánssyni sjötugum, ed. Gísli Sigurðsson, Guðrún Kvaran and Sigurgeir Steingrímsson (Reykjavík: Hið íslenska bókmenntafélag, 1994), pp. 641-52.

53 Jónas Gíslason, 'Acceptance of Christianity', p. 225; Biskupa sögur II, ed. Ásdís Egilsdóttir (Reykjavík: Hið íslenzka fornritafélag, 2002), pp. 6, 14. For continental influences on the early Icelandic church, see Peter Foote, 'Aachen, Lund, Hólar', in Aurvandilstá: Norse Studies (Odense: Odense University Press, 1984), pp. 101-20. ${ }^{54}$ Ólafur Halldórsson, 'Gægst á ársalinn Pórgunnu', in Grettisfarla: Safn ritgerða eftir Ólaf Halldórsson (Reykjavík: Stofnun Ârna Magnússonar, 1990), pp. 475-80. On Pórgunna and the supernatural events that she appears to unleash, see Kjartan G. Óttósson, Fróðarundur í Eyrbyggju (Reykjavík: Bókaútgáfa Menningarsjóðs, 1983); Knut Odner, 'Pórgunna's testament: a myth for moral contemplation and social apathy', in From Sagas to Society: Comparative Approaches to Early Iceland, ed. Gísli Pálsson (Enfield Lock: Hisarlik Press, 1992), pp. 125-46; Forrest S. Scott, 'The woman who knows; Female characters of Eyrbyggja Saga', in Cold Counsel: Women in Old Norse Literature and Mythology, ed. Sarah Anderson and Karen Swenson (New York and London: Routledge, 2002), pp. 225-43; Kirsi Kanerva, 'The Role of the Dead in Medieval Iceland: A Case Study of Eyrbyggja saga', Collegium Medievale 24 (2011), 23-49.

${ }^{55}$ On the different redactions of Landnámabók, see Jón Jóhannesson, Gerðir Landnámabókar (Reykjavík: Félagsprentsmiðjan, 1941), Sveinbjörn Rafnsson, Studier i Landnámabókar: kristiska bidrag till den isländske fristatstidens histora (Lund: Gleerup, 1974); Adolf Friðriksson and Orri Vésteinsson, 'Creating a Past: A Historiography of the Settlement of Iceland', in Contact, Continuity and Collapse: 
The Norse Colonization of the North Atlantic, ed. James H. Barrett (Turnhout: Brepols, 2003), pp. 139-61.

${ }^{56}$ Sverrir Jakobsson, 'Hauksbók and the Construction of an Icelandic World View', Saga-Book 31 (2007), 22-38.

${ }^{57}$ Elizabeth Ashman Rowe, 'Literary, Codicological and Political Perspectives on Hauksbók', Alvíssmál 19 (2008), 51-76. For Haukr's interest in the Irish, see Helgi Guðmundsson, Um Kjalnesinga sögu: nokkrar athuganir (Reykjavík: Bókarútgáfa Menningarsjóðs, 1967), pp. 73-77; Sveinbjörn Rafnsson, Studier i Landnámabókar, p. 78; Judith Jesch, 'Early Christians in Icelandic History - A Case Study', Nottingham Medieval Studies 31 (1987), pp. 19-20, 27.

${ }^{58}$ On Kristni saga and its relationship to Landnámabók, see further Íslendingabók, Kristni saga, pp. xxxii-xxxiii; Sveinbjörn Rafnsson, Sögugerð Landnámabókar: Um íslenska sagnaritun á 12. og 13. öld, pp. 25-32; Helgi Skúli Kjartansson, 'Af Resensbók, Kristni sögum ok Landnámuviðaukum', Gripla 12 (2011), 161-80 ${ }^{59}$ Jonas Wellendorf, 'The Interplay of Pagan and Christian Traditions in Icelandic Settlement Myths', Journal of English and Germanic Philology 109 (2010), 15-16. ${ }^{60}$ Life of St Declan of Ardmore, trans. Rev. P. Power (London: Irish Texts Society), p. 13; Lives of the Cambro-British Saints, ed. and trans. William Jenkins Rees (Llandovery: William Rees, 1853), pp. 99, 398.

${ }^{61}$ On 'sites of memory', see Smith, Myths and Memories, p. 151; Hermann, 'Founding Memories', p. 78.

${ }^{62}$ Biskupa sögur I, 15-16. Stefnir is a descendent of Helgi bjóla, who was the brother of Ørlygr's father Hrappr. However, in Stefnis páttr, we are informed that he 'tók trú' ('received the faith') in Denmark (Biskupa sögur, I, 103).

${ }^{63}$ Biskupa sögur I, 24, 138-39; also in Brennu-Njáls saga, ed. Einar Ólafur Sveinsson, Íslensk fornrit 12 (Reykjavík: Hið íslenzka fornritafélag, 1954), pp. 265-67.

${ }^{64}$ Wellendorf, 'Interplay', pp. 13-18; see also Margaret Clunies Ross, 'Land-Taking and Text-Making in Medieval Iceland', in Text and Territory: Geographical Imagination in the European Middle Ages, ed. Sylvia Tomasch and Sealy Gilles (Philadelphia: University of Pennsylvania Press, 1998), pp. 160, 172-74; William Sayers, 'Management of the Celtic Fact in Landnámabók', Scandinavian Studies 66 (1994), pp. 137-38; Eleanor R. Barraclough, 'Naming the Landscape in the Landnám Narratives of the Íslendingasögur and the Landnámabók', Saga-Book 26 (20012), pp. 93-95.

${ }^{65}$ Kjalnesinga saga, ed. Jóhannes Halldórsson, Íslensk fornrit 14 (Reykavík: Hið íslenzka fornritafélag, 1959), pp. 10, 12-13.

${ }^{66}$ Biskupa sögur I, 15-16, 105-106

${ }^{67}$ Robert Cook, 'The historical pattern of Kjalnesinga saga', in Sagnaping helgað Jónasi Kristjánssyni sjötugum, pp. 119-28.

${ }^{68}$ Margaret Schlauch, Romance in Iceland (London: George Allen \& Unwin, 1934), pp. 114-16; Einar Ól. Sveinsson, 'Celtic Elements in Icelandic Tradition', Béaloideas 25 (1957), 15; Helgi Guðmundsson, Um Kjalnesinga sögu, pp. 92-94.

${ }^{69}$ Landnámabók, p. 139.

${ }^{70}$ Landnámabók, p. 250; Víga-Glúms saga, ed. Gabriel Turville-Petre (Oxford:

Clarendon Press, 1960), p. 51. On Kolr, see Biskupa sögur I, 9.

${ }^{71}$ Sayers, 'Management of the Celtic Fact', p. 141.

72 Jesch, 'Early Christians', pp. 20, 27.

${ }^{73}$ Wellendorf, 'Interplay', pp. 12-13. 
${ }^{74}$ For similar fishing miracles, see Biskupa sögur I, 83-85; II, 130-31, 232, 293;

Biskupa sögur, 2 vols, ed. Jón Sigurðarson and Guðbrand Vigfússon (Copenhagen:

Hið íslenzka bókmenntafélag, 1858-78), I, 593-94 with an embedded reference to a similar miracle in the Life of St Martin; Harðar saga, Bárðar saga, Porskfirðinga saga, Flóamanna saga, ed. Pórhallur Vilmundarson and Bjarni Vilhjálmsson, Íslensk fornrit 13 (Reykjavík: Hið íslenzka fornritafélag, 1991), pp. 252, 283.

${ }^{75}$ Adomnan's Life of Columba, i. 6, pp. 28-30.

${ }^{76}$ Jesch, 'Early Christians', pp. 22-27. For Haukr's view of Iceland as the periphery of the world, see Sverrir Tómasson, 'Hauksbók', pp. 27-28; on the importance of saints to areas on the periphery of Christendom, see Patrick Geary, 'Reflections on Historiography and the Holy: Center and Periphery', in Saints and their Lives on the Periphery: Veneration of Saints in Scandinavia and Eastern Europe (c. 1000-1200), ed. Haki Antonsson and Ildar H. Garipzanov (Turnhout: Brepols, 2010), pp. 323-30. 77 On Hróðólfr, see Biskupa sögur, II, 11f; Jón Stefánsson, 'Rúðólf of Bæ and Rudolf of Rouen', Saga-Book 13 (1946-53), 174-82.

${ }^{78}$ Clunies Ross, “'Saint” Ásólfr', pp. 45-47.

${ }^{79}$ Biskupa sögur, I, 5-6.

${ }^{80}$ Clunies Ross, “Saint” Ásólfr', p. 36; 1 Corinthians 1:18-21, 3:19, 4:10. On the Christian tradition of 'holy fools', which was particularly strong in Ireland; see John Saward, Perfect Fools: Folly for Christ's Sake in Catholic and Orthodox Spirituality (Oxford: Oxford University Press, 1980), pp. 31-47.

${ }^{81}$ Orri Vésteinsson, The Christianization of Iceland: Priests, Power and Social

Change 1000-1300 (Oxford: Oxford University Press, 2000), pp. 130, 137-39.

${ }^{82}$ Sayers, 'Management of the Celtic Fact', p. 141.

${ }^{83}$ Hermann Pálsson, Keltar á Íslandi, p. 139.

${ }^{84}$ Sigurður Nordal, 'Pangbrandur á Mýrdalssandi', in Festskrift til Finnur Jónsson, ed. Johs. Brøndum-Nielsen et al. (Copenhagen: Levin \& Munksgaard, 1928), pp. 11320.

${ }^{85}$ Biskupa sögur, II, 58, 151. 